Article

\title{
Biogas Plant Exploitation in a Middle-Sized Dairy Farm in Poland: Energetic and Economic Aspects
}

\author{
Patrycja Pochwatka ${ }^{1}$, Alina Kowalczyk-Juśko ${ }^{1, *}$, , Piotr Sołowiej $^{2}{ }^{\circledR}$, \\ Agnieszka Wawrzyniak ${ }^{3}$ and Jacek Dach ${ }^{4}$ (D) \\ 1 Department of Environmental Engineering and Geodesy, University of Life Sciences in Lublin, \\ Leszczyńskiego 7, 20-069 Lublin, Poland; patrycja.pochwatka@up.lublin.pl \\ 2 Department of the Electrotechnics Energetics Electronics and Automatics, \\ University of Warmia and Mazury in Olsztyn, Oczapowskiego 11, 10-736 Olsztyn, Poland; pit@uwm.edu.pl \\ 3 Institute of Technology and Life Sciences, Falenty, Hrabska 3, 05-090 Raszyn, Poland; \\ a.wawrzyniak@itp.edu.pl \\ 4 Department of Biosystems Engineering, Poznan University of Life Sciences, Wojska Polskiego 50, \\ 60-637 Poznan, Poland; jacek.dach@up.poznan.pl \\ * Correspondence: alina.jusko@up.lublin.pl
}

Received: 3 November 2020; Accepted: 17 November 2020; Published: 19 November 2020

\begin{abstract}
Although cow manure is a valuable natural fertilizer, it is also a source of extreme greenhouse gas emissions, mainly methane. For this reason, this study aims to determine the impact of investments in a biogas plant on the energy and economic aspects of the operation of a dairy farm. A farm with a breeding size of 600 livestock units (LSU) was adopted for the analysis. In order to reach the paper's aim, the analysis of two different scenarios of dairy farm functioning (conventional-only milk production, and modern-with biogas plant exploitation) was conducted. The analysis showed that the investment in biogas plant operations at a dairy farm and in using cow manure as one of the main substrates is a more profitable scenario compared to traditional dairy farming. Taking into account the actual Polish subsidies for electricity produced by small biogas plants, the scenario with a functioning biogas plant with a capacity of $500 \mathrm{~kW}$ brings $€ 332,000 /$ a more profit compared to the conventional scenario, even when taking into account additional costs, including the purchase of straw to ensure a continuous operation of the installation. Besides, in the traditional scenario, building a biogas plant allows for an almost complete reduction of greenhouse gas emissions during manure storage.
\end{abstract}

Keywords: biogas plant; energetic optimization; substrates; manure; wheat straw

\section{Introduction}

\subsection{Methane as a Greenhouse Gas}

Methane, right after carbon dioxide, is considered to be the greenhouse gas that is the most harmful to the climate [1]. Almost 59\% of the world's emissions of this gas are of anthropogenic origin, of which the largest share (40-53\%) is agriculture, especially intensive production [2]. In the $\mathrm{EU}$, the share of agriculture in anthropogenic methane emissions is $53 \%, 26 \%$ is methane from waste, and $19 \%$ comes from energy production [3]. The reduction of methane emissions slows down negative climate changes and improves air quality [4]. Most of the legal acts concerning climate policy pay mostly attention to limiting carbon dioxide emissions. However, more and more attention is paid to the reduction of methane emissions [5]. The European Green Deal Communication emphasizes that reducing methane emissions related to the energy sector is one of the goals in achieving climate 
neutrality by 2050 [6]. In turn, the EU strategy to reduce methane emissions emphasizes that biogas production in anaerobic digesters from animal waste (i.e., manure) can be one of the solutions for reducing methane emissions to the atmosphere $[7,8]$.

\subsection{Dairy Production as Important Source of Methane Emission}

Ruminants are animals whose digestive tracts emit large amounts of methane [4]. A typical high-performance dairy cow produces up to $250 \mathrm{dm}^{3}$ of methane daily [9]. Many scientific teams research ways to reduce this emission by modifying the animal's diet or using various additives that reduce the activity of methane in cows' stomachs [10-14]. This is due to the fact that the emission of methane from the digestive system of ruminants reduces the milk yield of animals [15-17]. However, numerous studies show that it is challenging to significantly reduce methane emissions from intensive cattle farming [18-20].

The proper management of livestock manure has a much greater potential to reduce methane emissions, especially in the case of cattle manure [21-23]. It should be emphasized that manure stored in piles is a source of important methane emissions, the scale of which may reach tens of thousands of tons per year in Poland [24]. This emission mechanism is related to the typical practices of farmers who remove manure and form piles without pressing them immediately to remove air from inside the piles-as is done when forming silage corn piles $[25,26]$. However, there is still some air in a carelessly stacked pile. Cattle manure is an energy material, so bacteria break down easily decomposable chemicals in the presence of oxygen, producing $\mathrm{CO}_{2}$, water vapor, and a large amount of heat $[27,28]$. On the one hand, this process creates anaerobic conditions inside the heap, and on the other, it increases the heap's temperature to a level between 35 and $55^{\circ} \mathrm{C}[29,30]$. In this way, anaerobic conditions inside the heap are created, similar to those prevailing inside fermenters in a biogas plant, promoting intensive methane production [31,32]. Therefore, it should be emphasized that in dairy production, the manure removed every day should be immediately transferred to the biogas plant and subjected to the fermentation process there-but under controlled conditions [33-35].

A much lower intensity of methane production occurs from the slurry stored in the tanks $[36,37]$. This is mainly due to the much lower storage temperature of the slurry than that of the manure in noncompacted piles $[38,39]$. During storage, slurry stored at a temperature from a few to several degrees Celsius generates methane emissions, but at a level that is many times lower than for farmyard manure stored in piles $[40,41]$.

\subsection{Opportunities in Biogas Production}

Additionally, the production of biogas in agricultural areas may provide additional income from agricultural activities, which is an opportunity to develop the local economy in rural areas and promote circular economy principles in local communities [42-44]. Biogas is considered a renewable energy source $[45,46]$. Therefore, its production allows the increase of the share of these sources in the national energy mix, which is the EU's goal as set out in the renewable energy directive (RED II) [47]. A biogas plant can be a significant source of additional income for a farm specialized in dairy production. Energy prices are more stable than prices for agricultural products, including milk [48,49]. Therefore, a biogas plant located next to a dairy farm is a very environmentally friendly and logical solution $[50,51]$. What is more, perhaps shortly, breeding dairy cows in the European Union will have to be combined with the need to treat manure as a substrate in biogas plants. This is because it is related to the European Commission's activities aimed at reducing greenhouse gas emissions [2,52]. However, currently, methane emissions are not covered by any fee system - as is the case with $\mathrm{CO}_{2}$ emissions [5]. It is worth emphasizing that the use of manure as input for a biogas plant does not result in a loss of its fertilizing value because all macro- and microelements, except for carbon, will be found in the postfermentation pulp $[53,54]$.

What is more, apart from financial benefits (from the sale of electricity and heat or biomethane), promoting good social attitudes towards the environment, and increasing the share of renewable 
energy in the energy mix, biogas production can positively affect the quality of the soil $[55,56]$. The final byproduct of the production of biogas is digestate $[57,58]$. It is a highly absorbable natural fertilizer, the product of the anaerobic digestion process [59,60]. Digestate from biogas production is considered to be an organic or organomineral fertilizer [61]. Due to the dry organic matter content not exceeding $8 \%$, it can be poured onto fields, just like slurry [62]. Digestate contains phosphorus, nitrogen, and potassium and has a neutral to alkaline $\mathrm{pH}$, making it a good fertilizer [63]. Moreover, the digestion of manure can significantly reduce methane emissions from storages [64]. The barrier to using digestate may be the oversized content of heavy metals and microbiological contaminants, but this case happens mainly when urban sewage sludge is used for fermentation (not considered in the case of agricultural biogas plants). These compounds' content must be checked before using digestate as a fertilizer $[65,66]$.

\subsection{Manure and Wheat Straw as Biogas Plant Feedstock}

The manure generated in dairy production should necessarily be used as a substrate for biogas plants $[67,68]$. However, this is not about its average energy value but about avoiding methane emissions during manure storage in heaps [21,31]. After passing through the fermentation process in a biogas plant, manure is processed into a digested pulp, which is already devoid of significant energy value [69]. However, its effect on the soil is friendlier than that of manure or, especially, slurry because of the much lower biological and chemical oxygen demand (BOD and COD) [70,71]. In Poland, due to legal and economic conditions (the level of subsidies for the produced energy in particular), the most optimal way is to build a biogas plant with a capacity of $500 \mathrm{~kW} \mathrm{[72].} \mathrm{Such} \mathrm{an} \mathrm{installation} \mathrm{is} \mathrm{treated} \mathrm{as}$ a small biogas plant, and its construction requires only a simplified administrative path (basically the three most important documents). However, feeding a $500 \mathrm{~kW}$ biogas plant with only cow manure would require well over 1000 cows on a large scale. It has to be underlined that the term "small" biogas plant, in Polish regulations, means something completely different than the typical understanding in the wider world. In South Asia or Africa, there are millions of tiny biogas plants working with the manure produced by a few cows [73]. However, the climate in these areas creates very favorable conditions for the fermentation process (a high temperature, which excludes the necessity for fermenter heating). In Poland, which is located in Central Europe, it is impossible to exploit biogas plants without a special heating system, while the temperature during wintertime can reach down to $-20^{\circ} \mathrm{C}$. That is why only installations with fairly big fermenters (several hundred cubic meters) make technological sense, as their biogas production is sufficient to heat themselves and generate a surplus of energy [74,75].

Meanwhile, in Poland and many EU countries, the most common farm sizes comprise between 100 and 500 cows [76]. Therefore, supplementation with additional biological material is required to ensure a 500-kW biogas plant's continuous operation on a farm of this size. One of the most effective agricultural substrates is straw [77]. Straw has a 2-3-fold higher methane production potential than maize silage, the most popular substrate used by agricultural biogas plants in Europe [78-80]. At the same time, cereals are widely cultivated, thanks to which straw availability is at a high level throughout the country. For this reason, farmers are increasingly using it as a substrate for biogas plants [81]. However, it should be emphasized that the use of straw without an appropriate pretreatment may cause technological problems in biogas plants through the formation of scum, leading up to and including fermentation being stopped $[82,83]$. Therefore, in order to use straw for biogas plants, it must be very finely shredded; the best techniques for this are to break down lignocellulosic structures at the cellular level, for instance with extrusion, cavitation, or micronization [84-88]. Heat treatment techniques such as Steam Explosion are also very beneficial here [89]. It is worth adding that problems with the formation of scum do not occur in fermentation tanks with a central agitator, such as in the Dynamic Biogas technology [90].

This paper aimed to analyze two scenarios of dairy farm functioning: a conventional one (based mainly on profits from milk production) and a second scenario that included biogas plant exploitation with the usage the cow manure as one of the main substrates, where additional profits from sold energy, 
heat, and digestate were present. It has to be underlined that the dairy waste (like cheese whey) [91] can also be potentially used as an energetic substrate for biogas plants; however, in the described situation, the distance from the dairy factory was too far for the economic transport of waste for the planned biogas plant.

\section{Materials and Methods}

In order to reach the paper's aim, the analysis of two different scenarios of dairy farm functioning (conventional—only milk production, and modern—with biogas plant exploitation) were conducted. The main schema of the analytical and calculation procedures are shown in Figure 1.

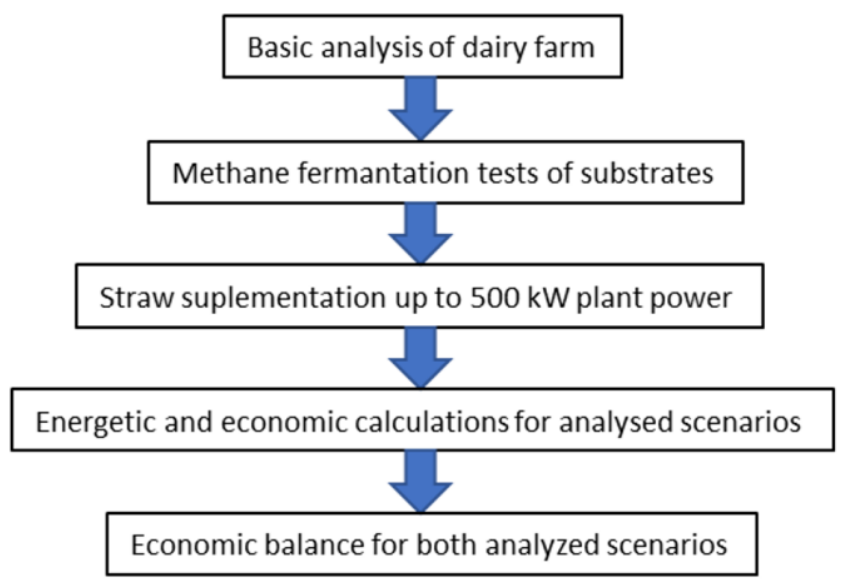

Figure 1. Methodological procedures for the energetic and economic analysis of both scenarios.

The paper's idea is based on a real investment planned to be realized in one of the Poznan University of Life Sciences (PULS) experimental farms. In this farm, dairy production from 600 cows is realized, and the investment for building a biogas plant with $500 \mathrm{~kW}$ of electric power is planned for 2021. At the end of 2019, PULS already finished a similar biogas plant at Przybroda experimental university farm ( $25 \mathrm{~km}$ west of Poznan) (Figure 2). However, the Przybroda biogas plant mainly uses biowaste (including food waste and waste from the agro-food industry) as its main substrates.

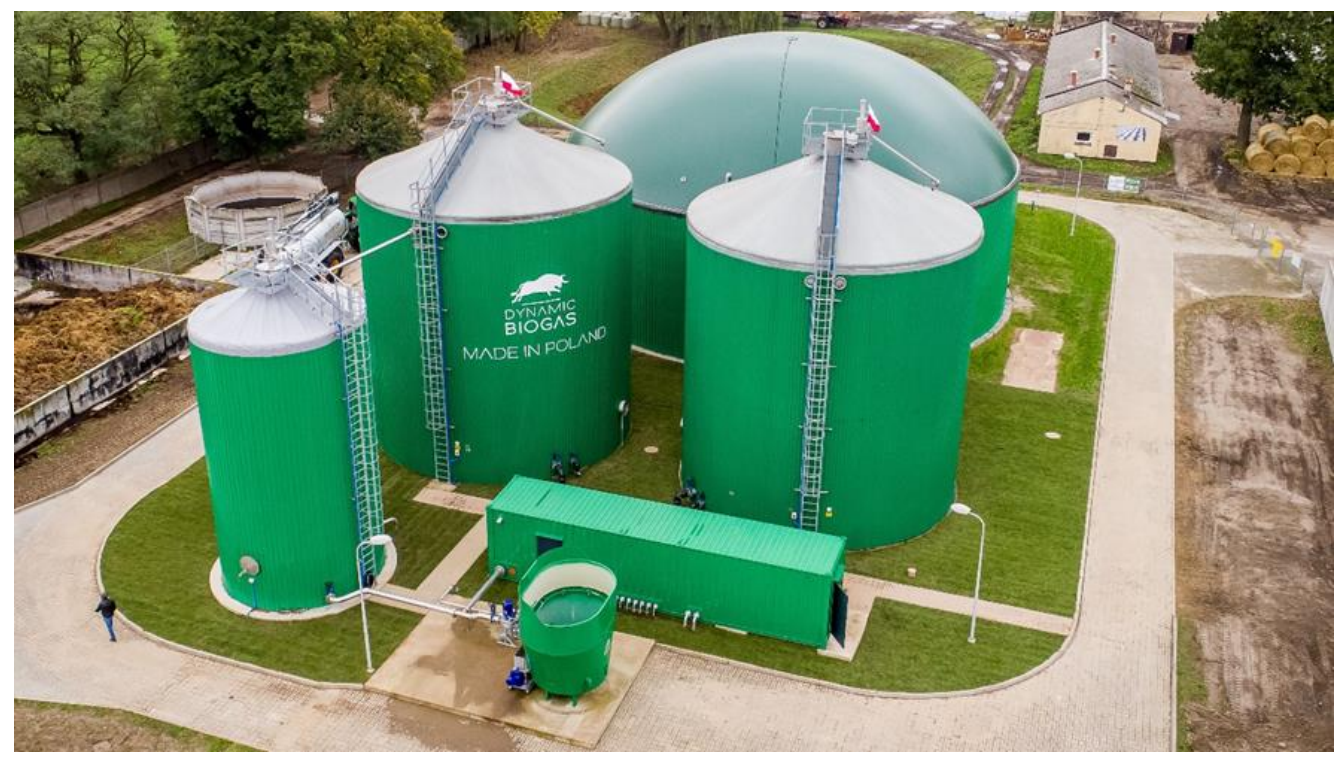

Figure 2. $500 \mathrm{~kW}$ biogas plant at Przybroda PULS experimental farm. 
The investment procedure made in the case of the biogas plant building should be based on strong economic and energetic arguments. It has to be underlined that the decision about the construction of biogas plants is usually related to a cost of several million euros. That is why this decision should be taken while considering several steps that let one reach the proper choice. The good practice is to follow the way that is shown in Figure 3.

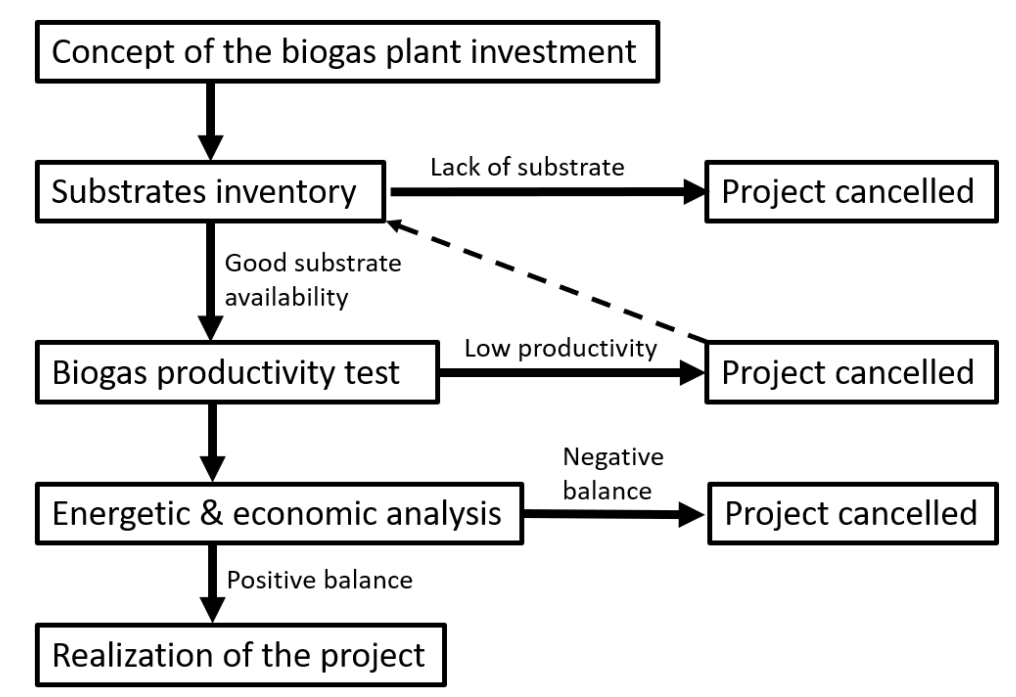

Figure 3. The flowchart of the proper way for making decisions for biogas plant investment.

\subsection{Biogas Production Efficiency from Substrates}

The biogas production efficiency analysis from substrates (manure and straw) was made in the Ecotechnologies Laboratory at Poznan University of Life Sciences, the biggest Polish biogas laboratory. The test methodology was done within German norms DIN 38414/S8 [92] and VDI 4630 [93], the most popular analytical procedure used in the European biogas laboratories. The Ecotechnologies Laboratory was the first Polish biogas laboratory that passed the quality proficiency test organized by the German organizations Verband deutscher landwirtschaftlicher Untersuchungs- und Forschungsanstalten (VDLUFA) and Kuratorium für Technik und Bauwesen in der Landwirtschaft e.V. (KTBL).

The fermentation process runs in the glass reactors (volume $2 \mathrm{dm}^{3}$ ), well-closed with a weck system. The reactors are maintained at a stable temperature $\left(39^{\circ} \mathrm{C}, \pm 1{ }^{\circ} \mathrm{C}\right)$ by their placement inside the aquarium with heat water. The samples (about $50 \mathrm{~g}$ of organic dry matter) are put inside reactors (always in three replications) and then filled with inoculum. The blank samples (in three replications as well) are only filled with inoculum. Inoculum is produced from the liquid part of the digestate obtained from a typical biogas plant. The produced biogas goes to the plexiglass cylinder, where its volume is measured every $24 \mathrm{~h}$. The gas composition $\left(\mathrm{CH}_{4} 0-100 \%, \mathrm{CO}_{2} 0-100 \%, \mathrm{O}_{2} 0-25 \%, \mathrm{H}_{2} \mathrm{~S} 0-10,000 \mathrm{ppm}\right.$, and $\mathrm{NH}_{3} \mathrm{0}-1000 \mathrm{ppm}$ ) is measured using the special portable tool GA5000. This instrument is calibrated each week using the gases to calibration $\left(\mathrm{CH}_{4} 65 \%, \mathrm{CO}_{2} 35 \%, \mathrm{H}_{2} \mathrm{~S} 500 \mathrm{ppm}\right.$, and $\mathrm{NH}_{3} 100$ ppm) supplied by Linde Gas company. The obtained results for each material are reduced by the production from the blank samples and then recalculated to be expressed as biogas and methane production from $1 \mathrm{Mg}$ of FM (fresh matter) (as well as of TS and VS) of the analyzed sample.

The final results of the methane production efficiency from the substrates analyzed in laboratory tests sent from the Ecotechnologies Laboratory to the contractors are always expressed in $\mathrm{CH}_{4} \mathrm{~m}^{3}$ from $1 \mathrm{Mg}$ of FM. This value is indispensable for further energetic calculations of planned biogas plant exploitation. 


\subsection{Energetic and Economic Calculations}

The investment plan is to build the biogas plant with $500 \mathrm{~kW}$ of electric power in Dynamic Biogas technology. The reason for this size is related to Polish law regulations. Whole administrative procedures are simplified in building a biogas plant with a maximum electric power of $0.5 \mathrm{MW}$. Furthermore, this size is enough to reach a reasonable profit from electric energy production.

The electric energy $\left(E_{e}\right)$ production from methane produced yearly from used substrates was calculated as follow:

$$
\mathrm{Ee}=\mathrm{VCH}_{4} \cdot \mathrm{WCH}_{4} \cdot \eta \mathrm{e} \quad[\mathrm{MWh}]
$$

where:

$\mathrm{VCH}_{4}$-volume of methane produced from digested substrates $\left[\mathrm{m}^{3}\right]$;

$\mathrm{WCH}_{4}$ - energetic value of 1 cubic meter of methane $\left[9.968 \mathrm{kWh} \mathrm{m}^{-3}\right]$;

ne-electric efficiency of CHP unit [0.4].

A similar equation should be used to calculate the heat (thermal energy, $E_{t}$ ) amount emitted from the cogeneration unit (CHP):

$$
\mathrm{Et}=\mathrm{VCH}_{4} \cdot \mathrm{WCH}_{4} \cdot \eta \mathrm{t} \quad[\mathrm{MWh}]
$$

where:

$\mathrm{VCH}_{4}$-volume of methane produced from digested substrates $\left[\mathrm{m}^{3}\right]$;

$\mathrm{WCH}_{4}$-energetic value of 1 cubic meter of methane $\left[9.968 \mathrm{kWh} \mathrm{m}^{-3}\right]$;

$\eta t$ - thermal efficiency of CHP unit [0.45].

The calculation of biogas plant electric power $\left(\mathrm{P}_{\mathrm{e}}\right)$ is based on the electric energy amount produced during the whole year and the working time of CHP. This equation is presented below:

$$
\mathrm{Pe}=\mathrm{Ee} / \mathrm{t} \quad[\mathrm{MW}]
$$

where:

Ee-amount of electric energy produced yearly [MWh];

$\mathrm{T}$-working time of CHP during the whole year of exploitation [8400 h].

The amount of heat can also be expressed in GJ, which is the most common unit that is used in reality by enterprises and people. This amount can be easily calculated because $1 \mathrm{MWh}$ is equal to $3.6 \mathrm{GJ}$. As in the case of electric power $\left(\mathrm{P}_{\mathrm{e}}\right)$, a similar equation was used for thermal power $\left(\mathrm{P}_{\mathrm{t}}\right)$ calculations:

$$
\mathrm{P}_{\mathrm{t}}=\mathrm{E}_{\mathrm{t}} / \mathrm{t} \quad[\mathrm{MW}]
$$

where:

Et-amount of heat produced yearly [MWh];

T-working time of CHP during the whole year of exploitation [8400 h].

It should be underlined that in a typical biogas plant, the real working time (7200-8100 h/a) is firmly lower than the $8400 \mathrm{~h} /$ year value fixed before. This is related to many exploitation problems and breaks of biogas production by, i.e., mixing system failures and other mechanical damages. However, the biogas plants working in Dynamic Biogas technology have a unique construction of steel fermenters (with a central, vertical mixing system working with only one mixer that is easily exchanged) and can reach up to 8500 working hours per year in reality.

The investment cost for building the $0.5 \mathrm{MW}$ biogas plant in DB technology is 9 million PLN ( $€ 1.970$ million with a currency rate of $€ 1=4.56$ PLN). This means that the depreciation cost (for a 15 -year period of exploitation) is $€ 131,580 / \mathrm{a}$. 


\section{Results}

\subsection{Basic Characterization of Analyzed Dairy Farm}

The analyzed farm has over 1000 ha of planted area and a herd of 600 dairy cows (breeding size of 600 livestock units (LSU)), which produce milk at a high level of 11,000 L/LSU/a. The milk is delivered to the dairy for $0.29 € / \mathrm{L}$. The sale of milk is one of the primary income sources for the farm, as it amounts to $€ 1.925$ million (Table 1 ).

Table 1. Characterization of the analyzed dairy farm.

\begin{tabular}{ccc}
\hline Parameter & Unit & Value \\
\hline Price of milk & $€ / \mathrm{L}$ & 0.29 \\
Milk production & $\mathrm{L} / \mathrm{LSU} / \mathrm{a}$ & 11,000 \\
Number of cows & $\mathrm{LSU}$ & 600 \\
Income from the sale of milk & $€ 1000 / \mathrm{a}$ & 1925 \\
Manure weight & $\mathrm{Mg} / \mathrm{a}$ & 9855 \\
\hline
\end{tabular}

After being removed from breeding buildings, cow manure is stored in piles on concrete platforms and spread into the field three times a year for fertilization. The total mass of produced farmyard manure is $9855 \mathrm{Mg}$ per year. It should be emphasized that in the current situation, manure stored for several months a year is a source of uncontrolled methane emissions, which in the future may become a financial problem for the farm if the European Commission pushes the taxation of $\mathrm{CH}_{4}$ emissions, on an equal basis as $\mathrm{CO}_{2}$ currently, through.

\subsection{Methane Productivity Analysis}

The basic parameters, such as dry matter content (TS), organic dry matter (VS), methane content, biogas, and methane yield of substrates, used for the fermentation tests are presented in Table 2.

Table 2. The basic parameters and biogas yield of the tested materials.

\begin{tabular}{|c|c|c|c|c|c|c|}
\hline \multirow{2}{*}{ Substrate } & TS & VS & \multirow{2}{*}{ C:N Ratio } & Biogas & $\mathrm{CH}_{4}$ Content & $\mathrm{CH}_{4}$ \\
\hline & [\% FM] & [\% TS] & & {$\left[\mathrm{m}^{3} / \mathrm{Mg} \mathrm{FM}\right]$} & {$[\%]$} & {$\left[\mathrm{m}^{3} / \mathrm{Mg} \mathrm{FM}\right]$} \\
\hline Cow manure & 21.56 & 85.62 & $21: 1$ & 79.90 & 56.37 & 45.04 \\
\hline Wheat straw & 92.67 & 96.96 & $95: 1$ & 468.49 & 56.72 & 265.72 \\
\hline
\end{tabular}

The results of TS show the big difference between both materials. Farmyard manure contains mostly water (over 78\%) and more than 15\% ash, so the methane productivity from one ton of fresh matter ( $\left.45.04 \mathrm{~m}^{3} / \mathrm{Mg} \mathrm{FM}\right)$ is almost six times lower when compared to the wheat straw result (265.72 $\mathrm{m}^{3} / \mathrm{Mg}$ FM). That is why, from a biogas plant exploitation point of view, the usage of straw for installation feeding has a much higher profitability when compared to manure. The biogas obtained from the fermentation of wheat straw and manure had a similar methane content: 56.7 and $56.4 \%$ methane, respectively.

The fermentation charts for manure and wheat straw are presented in Figures 4 and 5. It has to be underlined that the samples of manure and straw had a different initial mass, so the results presented in the figures cannot be directly compared. However, for comparison, the biogas and methane productivities calculated in $\mathrm{m}^{3}$ from $1 \mathrm{Mg}$ of both materials are presented in Table 2. Moreover, Figures 4 and 5 are important for presenting the dynamic of the gas production and fermentation time. 


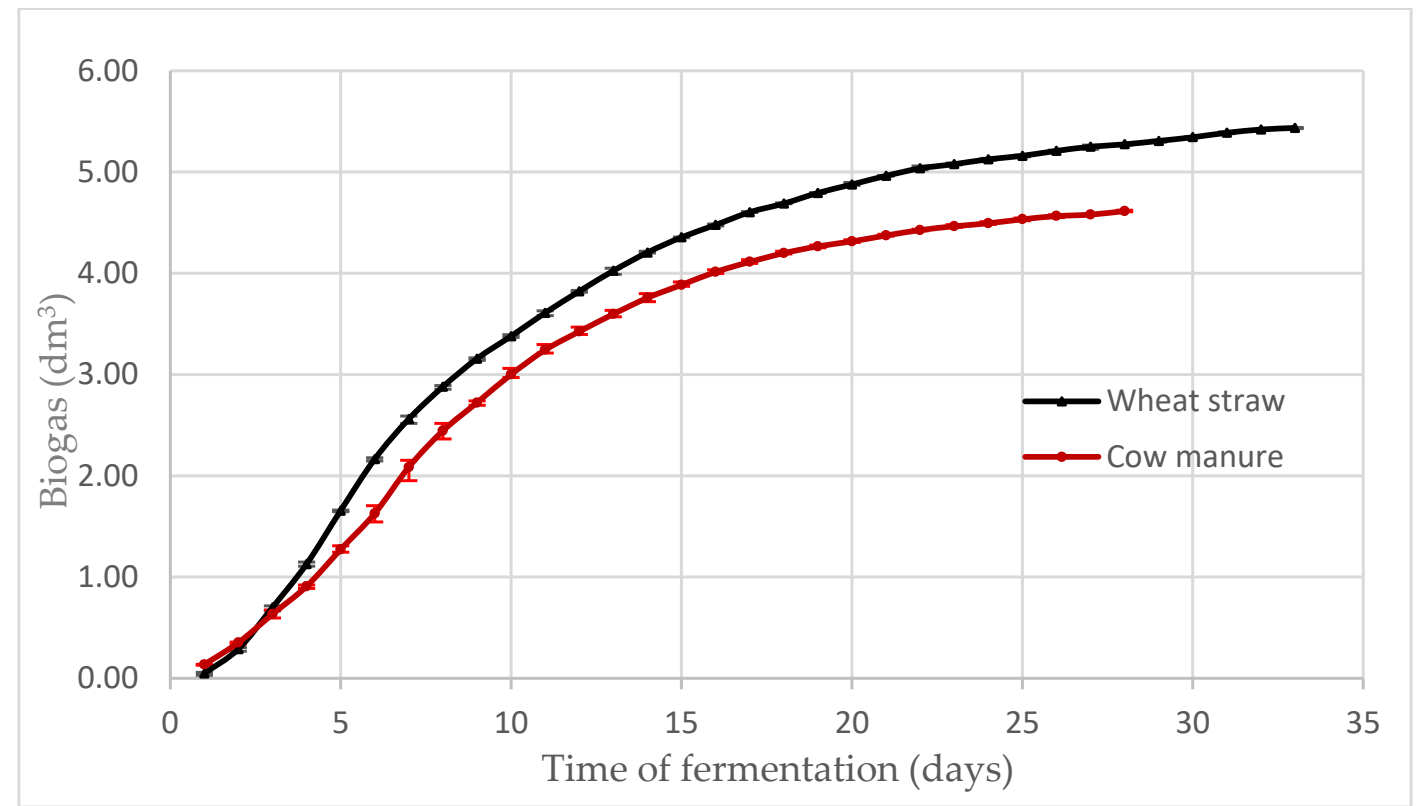

Figure 4. Production of biogas during the samples' fermentation process (daily measurements) for both materials, with error bars (the initial sample masses were different).

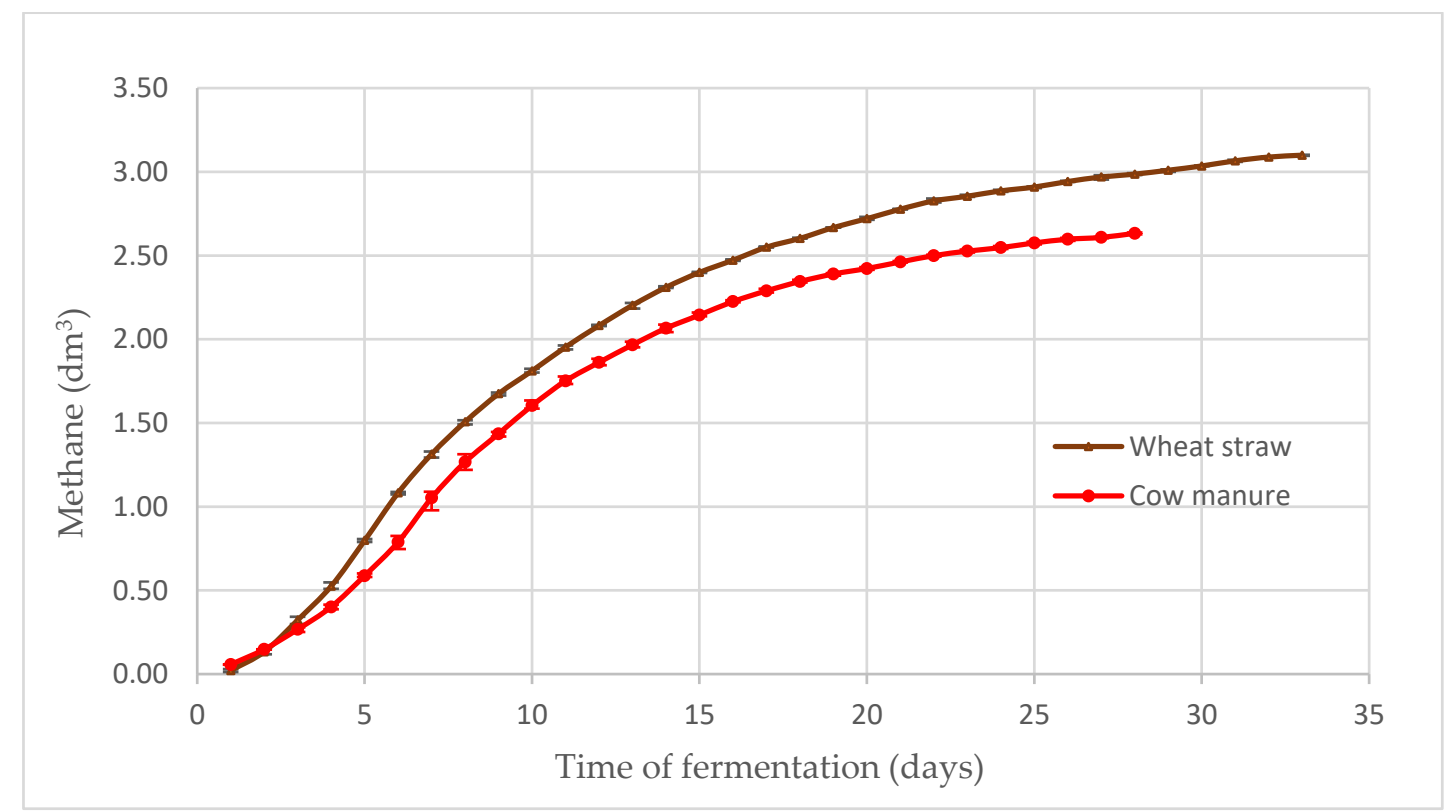

Figure 5. Methane production during the samples' fermentation process (daily measurements) for both materials, with error bars (the initial sample masses were different).

The runs of fermentation show that cow manure is digested in a shorter time (HRT (Hydraulic Retention Time) $=28$ days) than wheat straw (33 days). This phenomena is also visible in the periods for $80 \%$ and $90 \%$ of the total methane production (Figure 6). 


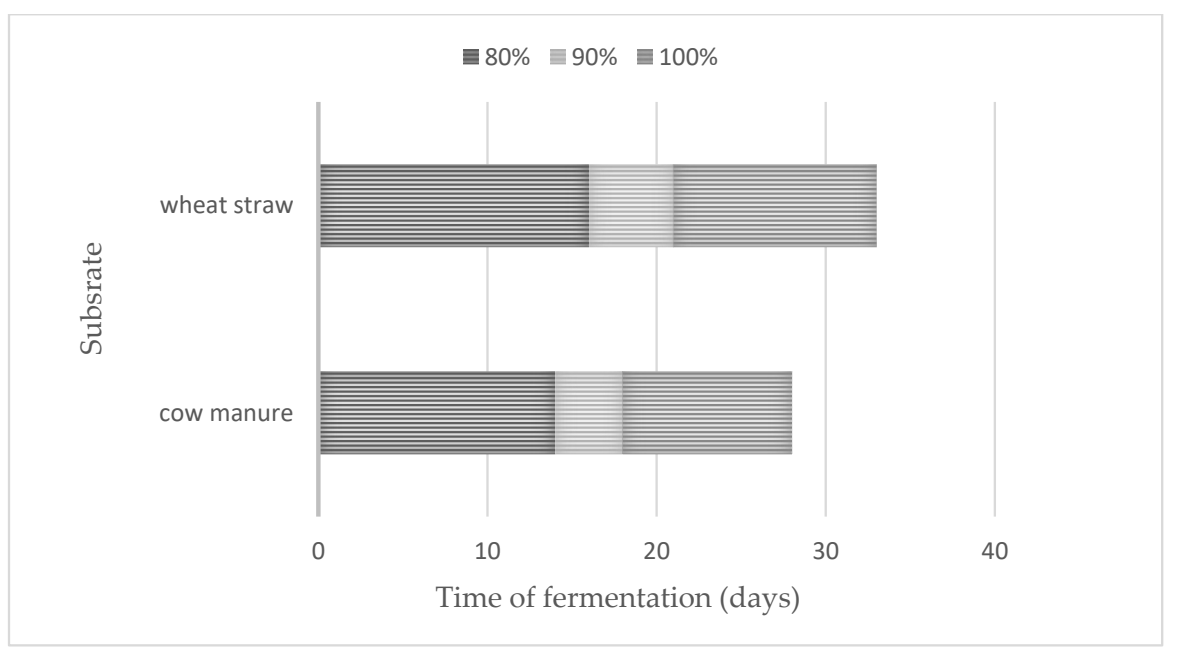

Figure 6. Time required for 80,90 , and $100 \%$ of total methane production for the analyzed materials.

$80 \%$ of total methane production was reached by cow manure on the 14th day; however, wheat straw needed 16 days to reach the same level (two days later). Those differences between manure and straw are bigger for $90 \%$ of the total production (three days), and the biggest difference is for the end of fermentation (five days).

\subsection{Energetic and Economic Calculations}

In the energy calculations, the first stage included the calculation of the electric power of the biogas plant, while only assuming work that used manure as a substrate. On this basis, it has been calculated that the production of methane from manure will amount to over $443,000 \mathrm{~m}^{3}$ annually, which will allow for the production of $1770 \mathrm{MWh}$ of electricity by a $0.211 \mathrm{MW}$ installation (Table 3).

As this capacity is less than half of the planned installation $(500 \mathrm{~kW})$, it was decided to obtain the missing capacity (0.289 MW) by using $2300 \mathrm{Mg}$ of wheat straw (Table 3).

Table 3. Energetic aspects of the biogas plant in the analyzed dairy farm.

\begin{tabular}{ccc}
\hline Parameter & Unit & Value \\
\hline $\mathrm{CH}_{4}$ yield of manure & $\mathrm{m}^{3} / \mathrm{Mg}$ & 45.04 \\
Amount of methane & $\mathrm{m}^{3} / \mathrm{a}$ & 443,869 \\
Electric energy & $\mathrm{MWh} / \mathrm{a}$ & 1770 \\
Electric power of the installation & $\mathrm{MW}_{\mathrm{e}}$ & 0.211 \\
\hline Additional substrate: wheat straw & & \\
The mass of straw & $\mathrm{Mg} / \mathrm{a}$ & 2300 \\
$\mathrm{CH}_{4}$ yield of straw & $\mathrm{m}^{3} / \mathrm{Mg}$ & 265.72 \\
Amount of methane & $\mathrm{m}^{3} / \mathrm{a}$ & 611,156 \\
Electric energy & $\mathrm{MWh} / \mathrm{a}$ & 2437 \\
Electric power of the installation & $\mathrm{MW} / \mathrm{e}$ & 0.289 \\
\hline Total amount of methane & $\mathrm{m}{ }^{3} / \mathrm{a}$ & $1,055,025$ \\
\hline Total electric energy & $\mathrm{MWh} / \mathrm{a}$ & 4207 \\
Total electric power & $\mathrm{MW} / \mathrm{e}$ & 0.500 \\
Electricity price & $\mathrm{EUR} / \mathrm{MWh}$ & 158.3 \\
Electricity value & $\mathrm{EUR} / \mathrm{a}$ & 666,044 \\
Amount of heat & $\mathrm{MWh} / \mathrm{a}$ & 4732 \\
Amount of heat & $\mathrm{GJ} / \mathrm{a}$ & 17,037 \\
Heat power & $\mathrm{MW}$ & 0.563 \\
Price for heat & $\mathrm{EUR} / \mathrm{GJ}$ & 8.77 \\
Heat value & $\mathrm{EUR} / \mathrm{a}$ & 134,500 \\
\hline
\end{tabular}


Ultimately, the designed installation will generate $1,055,025 \mathrm{~m}^{3}$ of methane, which, with a CHP unit electrical efficiency of $40 \%$, allows for the production of $4207 \mathrm{MWh}$ of electricity. When related to the $8400 \mathrm{~h}$ of operation of the cogeneration unit, this amount of energy allows $500 \mathrm{~kW}$ of electric power to be reached for the planned installation.

Since the current price (including subsidies from the state) for electricity for a 50-500-kW biogas plant in Poland is $158.3 € / \mathrm{MWh}$, the generated energy will bring revenues of over $€ 666,000$ per year.

The amount of heat, calculated according to a methodology similar to that of electricity, is over 17 TJ. When calculating the heat price, the price of heat produced from Poland's most popular energy carrier, i.e., hard coal, was used. In Poland, the value of heat generated from coal is $€ 8.77 / G J$. On this basis, the revenue from the sale of heat can be calculated, amounting to $€ 134,500$ per year (Table 4).

Table 4. Economic balance of the analyzed dairy farm in a conventional scenario (milk production) and in a scenario with milk production and biogas running.

\begin{tabular}{ccc}
\hline Parameter & Standard Scenario & Biogas Plant Scenario \\
\hline Sold milk & Profits [kEUR/a] & \\
Manure as fertilizer & 1925 & 1925 \\
Digestate as fertilizer & 259 & 74 \\
Electricity production & & 666 \\
Heat & & 135 \\
& Costs [kEUR/a] & \\
Straw cost & & -76 \\
Depreciation & & -132 \\
Service costs and others & $\mathbf{2 1 8 4}$ & $\mathbf{2 5 1 6}$ \\
Balance &
\end{tabular}

The total (simplified) economic balance of the dairy farm operation in two scenarios (traditional and in the version with a biogas plant processing cow manure and straw) shows a significant advantage of the second variant. The total profit in scenario II (€2.516 million) is $€ 332,000$ higher than in the traditional scenario. Considering the cost of building a biogas plant ( $€ 1.970$ million), this means that this installation will be paid back after six years of operation.

The described situation may change even more favorably for scenario II if the European Commission introduces taxes for methane emissions, similar to the current situation in the case of carbon dioxide. It should be taken into account that agriculture is a source of high methane emissions, and especially large amounts of methane are produced from heaps of cattle manure. The necessity to pay for emissions of methane-a greenhouse gas that is 21 times more powerful than $\mathrm{CO}_{2}$-will significantly worsen the profitability of scenario I (traditional). On this basis, it can be assumed that in the future, the construction of biogas plants at medium and large dairy farms will be necessary due to the reduction of uncontrolled methane emissions from stored manure.

\section{Discussion}

The paper describes an energetic and economic analysis of a dairy farm and small biogas plant coupling in order to increase farm profitability and decrease the uncontrolled methane emission from manure stored in heaps. However, some doubts may relate to the term "small" biogas plant, as in the described farm the planned installation has $500 \mathrm{~kW}$ of electric power and cannot be sufficiently fed with manure produced from 600 cows. In fact, when compared to the most popular biogas plant size in India and Southeast Asia (fermenters with a volume of only several cubic meters even, often located underground), this is a huge difference $[73,94]$. The main reason for this considerable difference in the definition of a small biogas plant is related to climate conditions. In Poland, temperatures reaching even $-20{ }^{\circ} \mathrm{C}$ in wintertime make it almost impossible to build small biogas plants like those in Asia because 
all constructed installations should be equipped with a heating system that allows the temperature inside fermenters to be kept at the level of $38-42{ }^{\circ} \mathrm{C}[95,96]$. Some trials in Poland, involving the construction of small biogas plants with a fermenter volume of $20-60 \mathrm{~m}^{3}$ and an installed power of 8-12 kW, showed that those installations were not able to produce enough biogas during wintertime to heat themselves and stabilize the temperature inside the fermenters. Furthermore, this is due to the high investment costs of operating such micro biogas plants, and, as a solution to this situation, Polish legislation defines a "small" biogas plant as an installation with installed electric power between 50 to $500 \mathrm{~kW}[97,98]$.

The usage of manure as a substrate for biogas plants is mentioned by many scientists as the best solution from an energetic, economic, and environmental point of view $[33,99,100]$. This can provide additional profit to animal farms (as was calculated in this paper) and can also reduce uncontrolled methane emissions to the atmosphere from manure stored in piles. What is especially interesting for human health is that anaerobic digestion can also destroy the antibiotics that are present in manure [101]. The massive usage of antibiotics in animal production and the subsequent uncontrolled stream of solved medicaments to the environment via animal (and human) excrements is the main reason for the creation of "super-bacteria" - resistant to all known antibiotics.

Some studies underline that (in general) animal manures should be treated by anaerobic digestion; however, these materials have a relatively weak biogas potential in order to guarantee a high productivity of biogas plants $[102,103]$. This was also the case in our study because whole manure production could cover less than half of the power in the planned installation. That is why the usage of additional substrates is required $[80,104]$. One of the most popular substrates is straw, which is easy to collect and has a high productivity. Many researchers have underlined the high value of different straws used for biogas feeding, like maize straw [77,105] or cereals [106]. In the described study, we need an additional $2300 \mathrm{Mg} / \mathrm{a}$ of wheat straw to keep the highest productivity of the planned biogas plant. It has to be underlined that straw usage for biogas plant feeding does not generate a conflict between food and biofuels production as is the case for maize silage usage. This is because straw is treated as an agricultural byproduct and not as the main yield.

The concept described in this paper is based on using only manure and straw for the feeding fermentation process. The reason for this concept is that both materials are produced on farms. However, it has to be underlined that the codigestion of different biowastes can generate a synergy effect and increase the total biogas production on a level that is higher than the sum of biogas generated separately by each substrate $[107,108]$. An excellent way to increase biogas productivity is the usage of dairy waste (i.e., cheese waste), brewery waste, and other materials (sometimes specific materials like biochar) $[109,110]$. In the described case, however, the dairy factory's distance was too big for the economic transport of dairy waste to the planned biogas plant.

\section{Conclusions}

Based on the research and results obtained, the following conclusions were formed:

1. Investment in a biogas plant operating at a dairy farm and using cow manure as one of the main substrates is a more profitable scenario than traditional dairy farming.

2. Currently, in Polish conditions, a scenario with a biogas plant operating with a capacity of $500 \mathrm{~kW}$ brings $332,000 € /$ a more profit than a conventional scenario (only milk production), even when taking into account additional costs, including the purchase of straw to ensure the continuous operation of the installation (manure from 600 cows will not provide substrate coverage).

3. In the analyzed case, the cost of building a biogas plant will pay off in less than six years. However, it is important to underline that this concerns the biogas plant with a power of $500 \mathrm{~kW}$ working with cow manure and wheat straw. Smaller-scale installations, as well as other substrates, can change this revenue time. 
4. The economic advantage of the dairy farm scenario with a biogas plant over the conventional variant will be even more significant if the European Commission introduces charges for methane emissions from agriculture (which will affect particular dairy farms that store manure in piles).

5. It should be necessary to develop and conduct energetic and economic analyses for scenarios based on smaller size installations and alternative substrates (dairy waste, food-industry waste, etc.).

Author Contributions: Conceptualization, P.P., A.K.-J., P.S., A.W. and J.D.; methodology, P.S. and J.D.; software, P.P.; validation, A.K.-J., P.S. and J.D.; formal analysis, P.P. and A.W.; investigation, P.P. and J.D.; resources, A.K.-J.; data curation, P.P. and A.W.; writing — original draft preparation, P.P. and A.K.-J.; writing—review and editing, P.P., A.K.-J., P.S., A.W. and J.D.; visualization, P.P.; supervision, J.D.; project administration, A.K.-J. and J.D.; funding acquisition, P.P. and A.K.-J. All authors have read and agreed to the published version of the manuscript.

Funding: This research was funded from the 'Excellent science' program of the Ministry of Science and Higher Education as a part of the contract no. DNK/SP/465641/2020 "The role of the agricultural engineering and environmental engineering in the sustainable agriculture development".

Acknowledgments: This paper was created in the framework of the project "Decision support system for sustainable and GHG optimised milk production in key European areas" No. ICT-AGRI-3 ID 39288, Acronym MilKey, realized at Poznan University of Life Sciences.

Conflicts of Interest: The authors declare no conflict of interest.

\section{References}

1. IPCC. Climate Change 2013: The Physical Science Basis. Contribution of Working Group I to the Fifth Assessment Report of the Intergovernmental Panel on Climate Change; Cambridge University Press: Cambridge, UK; New York, NY, USA, 2013; p. 1535. Available online: https://www.ipcc.ch/report/ar5/wg1/ (accessed on 1 October 2020).

2. IEA. World Energy Outlook. 2013. Available online: https://edgar.jrc.ec.europa.eu/overview.php?v=50_GHG (accessed on 1 October 2020).

3. EEA. EEA Greenhouse Gas—Data Viewer. 2013. Available online: https://www.eea.europa.eu/ds_resolveuid/ f4269fac-662f-4ba0-a416-c25373823292 (accessed on 1 October 2020).

4. Cole, N.A.; Meyer, B.E.; Parker, D.B.; Neel, J.; Turner, K.E.; Northup, B.K.; Jennings, T.; Jennings, J.S. Effects of diet quality on energy metabolism and methane production by beef steers fed a warm-season grass-based hay diet. Appl. Anim. Sci. 2020, 36, 652-667. [CrossRef]

5. EU 2030 Climate Target Plan Impact Assessment, Commission Staff Working Document Impact Assessment: Accompanying the Document Communication from the Commission to the European Parliament, the Council, the European Economic and Social Committee and the Committee of the Regions Stepping up Europe's 2030 Climate Ambition Investing in a Climate-neutral Future for the Benefit of our People. Available online: https://eur-lex.europa.eu/legal-content/EN/TXT/?uri=CELEX:52020SC0176 (accessed on 2 October 2020).

6. EGD. Communication on The European Green Deal. 2016. Available online: https://ec.europa.eu/info/ publications/communication-european-green-deal_en (accessed on 2 October 2020).

7. Matthews, C.; Crispie, F.; Lewis, E.; Reid, M.; O’Toole, P.W.; Cotter, P.D. The rumen microbiome: A crucial consideration when optimising milk and meat production and nitrogen utilisation efficiency. Gut Microbes 2019, 10, 115-132. [CrossRef] [PubMed]

8. Rojas-Downing, M.M.; Nejadhashemi, A.P.; Harrigan, T.; Woznicki, S.A. Climate change and livestock: Impacts, adaptation, and mitigation. Clim. Risk Manag. 2017, 16, 145-163. [CrossRef]

9. Leytem, A.B.; Dungan, R.S.; Bjorneberg, D.L.; Koehn, A.C. Emissions of Ammonia, Methane, Carbon Dioxide, and Nitrous Oxide from Dairy Cattle Housing and Manure Management Systems. J. Environ. Qual. 2011, 40, 1383-1394. [CrossRef]

10. Bryszak, M.; Szumacher-Strabel, M.; Huang, H.; Pawlak, P.; Lechniak, D.; Kołodziejski, P.; Yanza, Y.R.; Patra, A.K.; Váradyová, Z.; Cieslak, A. Lupinus angustifolius seed meal supplemented to dairy cow diet improves fatty acid composition in milk and mitigates methane production. Anim. Feed Sci. Technol. 2020, 267, 114590. [CrossRef]

11. Benchaar, C.; Hassanat, F. Methane emissions of stored manure from dairy cows fed conventional or brown midrib corn silage. J. Dairy Sci. 2019, 102, 10632-10638. [CrossRef] 
12. Kolling, G.J.; Stivanin, S.C.B.; Gabbi, A.M.; Machado, F.S.; Ferreira, A.L.; Campos, M.M.; Tomich, T.R.; Cunha, C.S.; Dill, S.W.; Pereira, L.G.R.; et al. Performance and methane emissions in dairy cows fed oregano and green tea extracts as feed additives. J. Dairy Sci. 2018, 101, 4221-4234. [CrossRef]

13. Lee, M.A.; Todd, A.; Sutton, M.A.; Chagunda, M.G.G.; Roberts, D.J.; Rees, R.M. A time-series of methane and carbon dioxide production from dairy cows during a period of dietary transition. Cogent Environ. Sci. 2017, 3, 1385693. [CrossRef]

14. Aemiro, A.; Hanada, M.; Umetsu, K.; Nishida, T. The effect of Sunphenon 30S-O on methane emission, nutrient intake, digestibility and rumen fermentation. Anim. Feed Sci. Technol. 2016, 214, 34-43. [CrossRef]

15. Gislon, G.; Colombini, S.; Borreani, G.; Crovetto, G.M.; Sandrucci, A.; Galassi, G.; Tabacco, E.; Rapetti, L. Milk production, methane emissions, nitrogen, and energy balance of cows fed diets based on different forage systems. J. Dairy Sci. 2020, 103, 8048-8061. [CrossRef]

16. Wanapat, M.; Cherdthong, A.; Phesatcha, K.; Kang, S. Dietary sources and their effects on animal production and environmental sustainability. Anim. Nutr. 2015, 1, 96-103. [CrossRef] [PubMed]

17. Knapp, J.R.; Laur, G.L.; Vadas, P.A.; Weiss, W.P.; Tricarico, J.M. Invited review: Enteric methane in dairy cattle production: Quantifying the opportunities and impact of reducing emissions. J. Dairy Sci. 2014, 97, 3231-3261. [CrossRef]

18. Benchaar, C.; Hassanat, F. Frequency of diet delivery to dairy cows: Effect on nutrient digestion, rumen fermentation, methane production, nitrogen utilization, and milk production. J. Dairy Sci. 2020, 103, 7094-7109. [CrossRef] [PubMed]

19. Bell, M.J.; Saunders, N.; Wilcox, R.H.; Homer, E.M.; Goodman, J.R.; Craigon, J.; Garnsworthy, P.C. Methane emissions among individual dairy cows during milking quantified by eructation peaks or ratio with carbon dioxide. J. Dairy Sci. 2014, 97, 6536-6546. [CrossRef] [PubMed]

20. Yan, T.; Mayne, C.S.; Gordon, F.G.; Porter, M.G.; Agnew, R.E.; Patterson, D.C.; Ferris, C.P.; Kilpatrick, D.J. Mitigation of enteric methane emissions through improving efficiency of energy utilization and productivity in lactating dairy cows. J. Dairy Sci. 2010, 93, 2630-2638. [CrossRef] [PubMed]

21. Uddin, M.E.; Larson, R.A.; Wattiaux, M.A. Effects of dairy cow breed and dietary forage on greenhouse gas emissions from manure during storage and after field application. J. Clean. Prod. 2020, 270, 122461. [CrossRef]

22. Wattiaux, M.A.; Uddin, M.E.; Letelier, P.; Jackson, R.D.; Larson, R.A. INVITED REVIEW: Emission and mitigation of greenhouse gases from dairy farms: The cow, the manure, and the field. Appl. Anim. Sci. 2019, 35, 238-254. [CrossRef]

23. Xue, B.; Wang, L.Z.; Yan, T. Methane emission inventories for enteric fermentation and manure management of yak, buffalo and dairy and beef cattle in China from 1988 to 2009. Agric. Ecosyst. Environ. 2014, 195, 202-210. [CrossRef]

24. Kozłowski, K.; Dach, J.; Lewicki, A.; Malińska, K.; Do Carmo, I.E.P.; Czekała, W. Potential of biogas production from animal manure in Poland. Arch. Environ. Prot. 2019, 45, 99-108. [CrossRef]

25. Thiruvenkatachari, R.R.; Carranza, V.; Ahangar, F.; Marklein, A.; Hopkins, F.; Venkatram, A. Uncertainty in using dispersion models to estimate methane emissions from manure lagoons in dairies. Agric. For. Meteorol. 2020, 290, 108011. [CrossRef]

26. VanderZaag, A.C.; Flesch, T.K.; Desjardins, R.L.; Baldé, H.; Wright, T. Measuring methane emissions from two dairy farms: Seasonal and manure-management effects. Agric. For. Meteorol. 2014, 194, 259-267. [CrossRef]

27. Ma, G.; Ndegwa, P.; Harrison, J.H.; Chen, Y. Methane yields during anaerobic co-digestion of animal manure with other feedstocks: A meta-analysis. Sci. Total Environ. 2020, 728, 138224. [CrossRef] [PubMed]

28. Jafari-Sejahrood, A.; Najafi, B.; Faizollahzadeh Ardabili, S.; Shamshirband, S.; Mosavi, A.; Chau, K. wing Limiting factors for biogas production from cow manure: Energo-environmental approach. Eng. Appl. Comput. Fluid Mech. 2019, 13, 954-966. [CrossRef]

29. Ding, L.; Lu, Q.; Xie, L.; Liu, J.; Cao, W.; Shi, Z.; Li, B.; Wang, C.; Zhang, G.; Ren, S. Greenhouse gas emissions from dairy open lot and manure stockpile in northern China: A case study. J. Air Waste Manag. Assoc. 2016, 66, 267-279. [CrossRef] [PubMed]

30. Wang, J.; Duan, C.; Ji, Y.; Sun, Y. Methane emissions during storage of different treatments from cattle manure in Tianjin. J. Environ. Sci. 2010, 22, 1564-1569. [CrossRef] 
31. Zhang, N.; Bai, Z.; Ledgard, S.; Luo, J.; Ma, L. Ammonia mitigation effects from the cow housing and manure storage chain on the nitrogen and carbon footprints of a typical dairy farm system on the North China Plain. J. Clean. Prod. 2021, 280, 124465. [CrossRef]

32. Flesch, T.K.; Desjardins, R.L.; Worth, D. Fugitive methane emissions from an agricultural biodigester. Biomass Bioenergy 2011, 35, 3927-3935. [CrossRef]

33. Díaz-Vázquez, D.; Alvarado-Cummings, S.C.; Meza-Rodríguez, D.; Senés-Guerrero, C.; de Anda, J.; Gradilla-Hernández, M.S. Evaluation of biogas potential from livestock manures and multicriteria site selection for centralized anaerobic digester systems: The case of Jalisco, Mexico. Sustainability 2020, 12, 3527. [CrossRef]

34. Feng, L.; Ward, A.J.; Moset, V.; Møller, H.B. Methane emission during on-site pre-storage of animal manure prior to anaerobic digestion at biogas plant: Effect of storage temperature and addition of food waste. J. Environ. Manag. 2018, 225, 272-279. [CrossRef]

35. Wang, Q.; Thompson, E.; Parsons, R.; Rogers, G.; Dunn, D. Economic feasibility of converting cow manure to electricity: A case study of the CVPS Cow Power program in Vermont. J. Dairy Sci. 2011, 94, 4937-4949. [CrossRef]

36. Massé, D.I.; Jarret, G.; Hassanat, F.; Benchaar, C.; Saady, N.M.C. Effect of increasing levels of corn silage in an alfalfa-based dairy cow diet and of manure management practices on manure fugitive methane emissions. Agric. Ecosyst. Environ. 2016, 221, 109-114. [CrossRef]

37. Sommer, S.G.; Petersen, S.O.; Søgaard, H.T. Greenhouse Gas Emission from Stored Livestock Slurry. J. Environ. Qual. 2000, 29, 744-751. [CrossRef]

38. VanderZaag, A.; Amon, B.; Bittman, S.; Kuczyński, T. Ammonia Abatement with Manure Storage and Processing Techniques. In Costs of Ammonia Abatement and the Climate Co-Benefits; Springer: Berlin/Heidelberg, Germany; Dordrecht, The Netherlands, 2015; pp. 75-112. [CrossRef]

39. Hindrichsen, I.K.; Wettstein, H.R.; Machmüller, A.; Kreuzer, M. Methane emission, nutrient degradation and nitrogen turnover in dairy cows and their slurry at different milk production scenarios with and without concentrate supplementation. Agric. Ecosyst. Environ. 2006, 113, 150-161. [CrossRef]

40. Kupper, T.; Häni, C.; Neftel, A.; Kincaid, C.; Bühler, M.; Amon, B.; VanderZaag, A. Ammonia and greenhouse gas emissions from slurry storage-A review. Agric. Ecosyst. Environ. 2020, 300, 106963. [CrossRef]

41. Browne, J.D.; Gilkinson, S.R.; Frost, J.P. The effects of storage time and temperature on biogas production from dairy cow slurry. Biosyst. Eng. 2015, 129, 48-56. [CrossRef]

42. Luo, T.; Khoshnevisan, B.; Huang, R.; Chen, Q.; Mei, Z.; Pan, J.; Liu, H. Analysis of revolution in decentralized biogas facilities caused by transition in Chinese rural areas. Renew. Sustain. Energy Rev. 2020, 133, 110133. [CrossRef]

43. Garcia, N.H.; Mattioli, A.; Gil, A.; Frison, N.; Battista, F.; Bolzonella, D. Evaluation of the methane potential of different agricultural and food processing substrates for improved biogas production in rural areas. Renew. Sustain. Energy Rev. 2019, 112, 1-10. [CrossRef]

44. Zemo, K.H.; Panduro, T.E.; Termansen, M. Impact of biogas plants on rural residential property values and implications for local acceptance. Energy Policy 2019, 129, 1121-1131. [CrossRef]

45. Korberg, A.D.; Skov, I.R.; Mathiesen, B.V. The role of biogas and biogas-derived fuels in a $100 \%$ renewable energy system in Denmark. Energy 2020, 199, 117426. [CrossRef]

46. Rosa, A.P.; Chernicharo, C.A.L.; Lobato, L.C.S.; Silva, R.V.; Padilha, R.F.; Borges, J.M. Assessing the potential of renewable energy sources (biogas and sludge) in a full-scale UASB-based treatment plant. Renew. Energy 2018, 124, 21-26. [CrossRef]

47. RED I. Renewable Energy-Recast to 2030 (RED II) EU Science Hub. 2013. Available online: https: //ec.europa.eu/jrc/en/jec/renewable-energy-recast-2030-red-ii (accessed on 10 October 2020).

48. Kozłowski, K.; Pietrzykowski, M.; Czekała, W.; Dach, J.; Kowalczyk-Juśko, A.; Jóźwiakowski, K.; Brzoski, M. Energetic and economic analysis of biogas plant with using the dairy industry waste. Energy 2019, 183, 1023-1031. [CrossRef]

49. Lauer, M.; Hansen, J.K.; Lamers, P.; Thrän, D. Making money from waste: The economic viability of producing biogas and biomethane in the Idaho dairy industry. Appl. Energy 2018, 222, 621-636. [CrossRef]

50. McVoitte, W.P.A.; Clark, O.G. The effects of temperature and duration of thermal pretreatment on the solid-state anaerobic digestion of dairy cow manure. Heliyon 2019, 5, e02140. [CrossRef] [PubMed]

51. Klavon, K.H.; Lansing, S.A.; Mulbry, W.; Moss, A.R.; Felton, G. Economic analysis of small-scale agricultural digesters in the United States. Biomass Bioenergy 2013, 54, 36-45. [CrossRef] 
52. Klootwijk, C.W.; Van Middelaar, C.E.; Berentsen, P.B.M.; de Boer, I.J.M. Dutch dairy farms after milk quota abolition: Economic and environmental consequences of a new manure policy. J. Dairy Sci. 2016, 99, 8384-8396. [CrossRef]

53. Vergote, T.L.I.; Bodé, S.; De Dobbelaere, A.E.J.; Buysse, J.; Meers, E.; Volcke, E.I.P. Monitoring methane and nitrous oxide emissions from digestate storage following manure mono-digestion. Biosyst. Eng. 2020, 196, 159-171. [CrossRef]

54. Khayum, N.; Anbarasu, S.; Murugan, S. Biogas potential from spent tea waste: A laboratory scale investigation of co-digestion with cow manure. Energy 2018, 165, 760-768. [CrossRef]

55. Vanden Nest, T.; Amery, F.; Fryda, L.; Boogaerts, C.; Bilbao, J.; Vandecasteele, B. Renewable P sources: P use efficiency of digestate, processed animal manure, compost, biochar and struvite. Sci. Total Environ. 2021, 750, 141699. [CrossRef]

56. Iocoli, G.A.; Zabaloy, M.C.; Pasdevicelli, G.; Gómez, M.A. Use of biogas digestates obtained by anaerobic digestion and co-digestion as fertilizers: Characterization, soil biological activity and growth dynamic of Lactuca sativa L. Sci. Total Environ. 2019, 647, 11-19. [CrossRef] [PubMed]

57. Ehmann, A.; Bach, I.M.; Bilbao, J.; Lewandowski, I.; Müller, T. Phosphates recycled from semi-liquid manure and digestate are suitable alternative fertilizers for ornamentals. Sci. Hortic. 2019, 243, 440-450. [CrossRef]

58. Czekała, W.; Bartnikowska, S.; Dach, J.; Janczak, D.; Smurzyńska, A.; Kozłowski, K.; Bugała, A.; Lewicki, A.; Cieślik, M.; Typańska, D.; et al. The energy value and economic efficiency of solid biofuels produced from digestate and sawdust. Energy 2018, 159, 1118-1122. [CrossRef]

59. Czekała, W.; Lewicki, A.; Pochwatka, P.; Czekała, A.; Wojcieszak, D.; Jóźwiakowski, K.; Waliszewska, H. Digestate management in polish farms as an element of the nutrient cycle. J. Clean. Prod. 2020, 242, 118454. [CrossRef]

60. Hung, C.Y.; Tsai, W.T.; Chen, J.W.; Lin, Y.Q.; Chang, Y.M. Characterization of biochar prepared from biogas digestate. Waste Manag. 2017, 66, 53-60. [CrossRef] [PubMed]

61. Törnwall, E.; Pettersson, H.; Thorin, E.; Schwede, S. Post-treatment of biogas digestate-An evaluation of ammonium recovery, energy use and sanitation. In Proceedings of the Energy Procedia; Elsevier Ltd.: Amsterdam, The Netherlands, 2017; Volume 142, pp. 957-963. [CrossRef]

62. Baral, K.R.; Labouriau, R.; Olesen, J.E.; Petersen, S.O. Nitrous oxide emissions and nitrogen use efficiency of manure and digestates applied to spring barley. Agric. Ecosyst. Environ. 2017, 239, 188-198. [CrossRef]

63. Castro, L.; Escalante, H.; Jaimes-Estévez, J.; Díaz, L.J.; Vecino, K.; Rojas, G.; Mantilla, L. Low cost digester monitoring under realistic conditions: Rural use of biogas and digestate quality. Bioresour. Technol. 2017, 239, 311-317. [CrossRef] [PubMed]

64. Maldaner, L.; Wagner-Riddle, C.; VanderZaag, A.C.; Gordon, R.; Duke, C. Methane emissions from storage of digestate at a dairy manure biogas facility. Agric. For. Meteorol. 2018, 258, 96-107. [CrossRef]

65. Yan, Y.; Zhang, L.; Feng, L.; Sun, D.; Dang, Y. Comparison of varying operating parameters on heavy metals ecological risk during anaerobic co-digestion of chicken manure and corn stover. Bioresour. Technol. 2018, 247, 660-668. [CrossRef]

66. Dahlin, J.; Herbes, C.; Nelles, M. Biogas digestate marketing: Qualitative insights into the supply side. Resour. Conserv. Recycl. 2015, 104, 152-161. [CrossRef]

67. Marin-Batista, J.D.; Villamil, J.A.; Qaramaleki, S.V.; Coronella, C.J.; Mohedano, A.F.; de la Rubia, M.A. Energy valorization of cow manure by hydrothermal carbonization and anaerobic digestion. Renew. Energy 2020, 160, 623-632. [CrossRef]

68. Møller, H.B.; Moset, V.; Brask, M.; Weisbjerg, M.R.; Lund, P. Feces composition and manure derived methane yield from dairy cows: Influence of diet with focus on fat supplement and roughage type. Atmos. Environ. 2014, 94, 36-43. [CrossRef]

69. Li, Y.; Achinas, S.; Zhao, J.; Geurkink, B.; Krooneman, J.; Willem Euverink, G.J. Co-digestion of cow and sheep manure: Performance evaluation and relative microbial activity. Renew. Energy 2020, 153, 553-563. [CrossRef]

70. Duan, N.; Khoshnevisan, B.; Lin, C.; Liu, Z.; Liu, H. Life cycle assessment of anaerobic digestion of pig manure coupled with different digestate treatment technologies. Environ. Int. 2020, 137, 105522. [CrossRef] [PubMed] 
71. Valentinuzzi, F.; Cavani, L.; Porfido, C.; Terzano, R.; Pii, Y.; Cesco, S.; Marzadori, C.; Mimmo, T. The fertilising potential of manure-based biogas fermentation residues: Pelleted vs. liquid digestate. Heliyon 2020, 6, e03325. [CrossRef] [PubMed]

72. Igliński, B.; Buczkowski, R.; Iglińska, A.; Cichosz, M.; Piechota, G.; Kujawski, W. Agricultural biogas plants in Poland: Investment process, economical and environmental aspects, biogas potential. Renew. Sustain. Energy Rev. 2012, 16, 4890-4900. [CrossRef]

73. Singh, P.; Singh, N. Political economy of bioenergy transitions in developing countries: A case study of Punjab, India. World Dev. 2019, 124, 104630. [CrossRef]

74. Stürmer, B.; Leiers, D.; Anspach, V.; Brügging, E.; Scharfy, D.; Wissel, T. Agricultural biogas production: A regional comparison of technical parameters. Renew. Energy 2021, 164, 171-182. [CrossRef]

75. Piwowar, A.; Dzikuć, M.; Adamczyk, J. Agricultural biogas plants in Poland-Selected technological, market and environmental aspects. Renew. Sustain. Energy Rev. 2016, 58, 69-74. [CrossRef]

76. Gieseke, D.; Lambertz, C.; Gauly, M. Relationship between herd size and measures of animal welfare on dairy cattle farms with freestall housing in Germany. J. Dairy Sci. 2018, 101, 7397-7411. [CrossRef]

77. Mazurkiewicz, J.; Marczuk, A.; Pochwatka, P.; Kujawa, S. Maize Straw as a Valuable Energetic Material for Biogas Plant Feeding. Materials 2019, 12, 3848. [CrossRef]

78. Kowalczyk-Juśko, A.; Pochwatka, P.; Zaborowicz, M.; Czekała, W.; Mazurkiewicz, J.; Mazur, A.; Janczak, D.; Marczuk, A.; Dach, J. Energy value estimation of silages for substrate in biogas plants using an artificial neural network. Energy 2020, 202, 117729. [CrossRef]

79. Cieślik, M.; Dach, J.; Lewicki, A.; Smurzyńska, A.; Janczak, D.; Pawlicka-Kaczorowska, J.; Boniecki, P.; Cyplik, P.; Czekała, W.; Jóźwiakowski, K. Methane fermentation of the maize straw silage under meso- and thermophilic conditions. Energy 2016, 115, 1495-1502. [CrossRef]

80. Dach, J.; Boniecki, P.; Przybył, J.; Janczak, D.; Lewicki, A.; Czekała, W.; Witaszek, K.; Rodríguez Carmona, P.C.; Cieślik, M. Energetic efficiency analysis of the agricultural biogas plant in $250 \mathrm{kWe}$ experimental installation. Energy 2014, 69, 34-38. [CrossRef]

81. Wandera, S.M.; Qiao, W.; Algapani, D.E.; Bi, S.; Yin, D.; Qi, X.; Liu, Y.; Dach, J.; Dong, R. Searching for possibilities to improve the performance of full scale agricultural biogas plants. Renew. Energy 2018, 116, 720-727. [CrossRef]

82. Abraham, A.; Mathew, A.K.; Park, H.; Choi, O.; Sindhu, R.; Parameswaran, B.; Pandey, A.; Park, J.H.; Sang, B.I. Pretreatment strategies for enhanced biogas production from lignocellulosic biomass. Bioresour. Technol. 2020, 301, 122725. [CrossRef] [PubMed]

83. Ramos-Suárez, J.L.; Gómez, D.; Regueiro, L.; Baeza, A.; Hansen, F. Alkaline and oxidative pretreatments for the anaerobic digestion of cow manure and maize straw: Factors influencing the process and preliminary economic viability of an industrial application. Bioresour. Technol. 2017, 241, 10-20. [CrossRef]

84. Li, P.; He, C.; Li, G.; Ding, P.; Lan, M.; Gao, Z.; Jiao, Y. Biological pretreatment of corn straw for enhancing degradation efficiency and biogas production. Bioengineered 2020, 11, 251-260. [CrossRef] [PubMed]

85. Victorin, M.; Davidsson, Å.; Wallberg, O. Characterization of Mechanically Pretreated Wheat Straw for Biogas Production. Bioenergy Res. 2020, 13, 833-844. [CrossRef]

86. Yu, Q.; Liu, R.; Li, K.; Ma, R. A review of crop straw pretreatment methods for biogas production by anaerobic digestion in China. Renew. Sustain. Energy Rev. 2019, 107, 51-58. [CrossRef]

87. Gallegos, D.; Wedwitschka, H.; Moeller, L.; Zehnsdorf, A.; Stinner, W. Effect of particle size reduction and ensiling fermentation on biogas formation and silage quality of wheat straw. Bioresour. Technol. 2017, 245, 216-224. [CrossRef]

88. Feng, Y.; Zhao, X.; Guo, Y.; Yang, G.; Xi, J.; Ren, G. Changes in the material characteristics of maize straw during the pretreatment process of methanation. J. Biomed. Biotechnol. 2012, 2012. [CrossRef]

89. Khoshnevisan, B.; Shafiei, M.; Rajaeifar, M.A.; Tabatabaei, M. Biogas and bioethanol production from pinewood pre-treated with steam explosion and N-methylmorpholine-N-oxide (NMMO): A comparative life cycle assessment approach. Energy 2016, 114, 935-950. [CrossRef]

90. Marks, S.; Dach, J.; Morales, F.J.F.; Mazurkiewicz, J.; Pochwatka, P.; Gierz, Ł. New trends in substrates and biogas systems in Poland. J. Ecol. Eng. 2020, 21, 19-25. [CrossRef]

91. Mainardis, M.; Flaibani, S.; Trigatti, M.; Goi, D. Techno-economic feasibility of anaerobic digestion of cheese whey in small Italian dairies and effect of ultrasound pre-treatment on methane yield. J. Environ. Manag. 2019, 246, 557-563. [CrossRef] [PubMed] 
92. DIN 38 414/S8. German Standard Methods for the Examination of Water, Waste Water and Sludge; Sludge and Sediments (Group S); Determination of the Amenability to Anaerobic Digestion (S 8); DIN Deutches Institut für Normung e. V.: Berlin, Germany, 2012.

93. VDI 4630. Fermentation of Organic Materials. Characterization of the Substrate, Sampling, Collection of Material Data, Fermentation Tests; Verein Deutscher Ingenieure e.V.: Düsseldorf, Germany, 2016.

94. Malik, W.; Mohan, C.; Annachhatre, A.P. Community based biogas plant utilizing food waste and cow dung. Mater. Today-Proc. 2020, 28, 1910-1915. [CrossRef]

95. Fjørtoft, K.; Morken, J.; Hanssen, J.F.; Briseid, T. Methane production and energy evaluation of a farm scaled biogas plant in cold climate area. Bioresour. Technol. 2014, 169, 72-79. [CrossRef] [PubMed]

96. Pham, C.H.; Vu, C.C.; Sommer, S.G.; Bruun, S. Factors affecting process temperature and biogas production in small-scale rural biogas digesters in winter in northern Vietnam. Asian-Australas. J. Anim. Sci. 2014, 27, 1050-1056. [CrossRef] [PubMed]

97. Igliński, B.; Piechota, G.; Iwański, P.; Skarzatek, M.; Pilarski, G. 15 Years of the Polish agricultural biogas plants: Their history, current status, biogas potential and perspectives. Clean Technol. Environ. Policy 2020, 22, 281-307. [CrossRef]

98. Chasnyk, O.; Sołowski, G.; Shkarupa, O. Historical, technical and economic aspects of biogas development: Case of Poland and Ukraine. Renew. Sustain. Energy Rev. 2015, 52, 227-239. [CrossRef]

99. Achinas, S.; Willem Euverink, G.J. Rambling facets of manure-based biogas production in Europe: A briefing. Renew. Sustain. Energy Rev. 2020, 119, 109566. [CrossRef]

100. Zareei, S. Evaluation of biogas potential from livestock manures and rural wastes using GIS in Iran. Renew. Energy 2018, 118, 351-356. [CrossRef]

101. Hosseini Taleghani, A.; Lim, T.-T.; Lin, C.-H.; Ericsson, A.C.; Vo, P.H. Degradation of Veterinary Antibiotics in Swine Manure via Anaerobic Digestion. Bioengineering 2020, 7, 123. [CrossRef]

102. Li, Y.; Zhao, J.; Achinas, S.; Zhang, Z.; Krooneman, J.; Euverink, G.J.W. The biomethanation of cow manure in a continuous anaerobic digester can be boosted via a bioaugmentation culture containing Bathyarchaeota. Sci. Total Environ. 2020, 745, 141042. [CrossRef]

103. Ahmed, S.; Einfalt, D.; Kazda, M. Co-Digestion of Sugar Beet Silage Increases Biogas Yield from Fibrous Substrates. Biomed Res. Int. 2016, 2016. [CrossRef]

104. Koryś, K.A.; Latawiec, A.E.; Grotkiewicz, K.; Kuboń, M. The Review of Biomass Potential for Agricultural Biogas Production in Poland. Sustainability 2019, 11, 6515. [CrossRef]

105. Zbytek, Z.; Dach, J.; Pawłowski, T.; Smurzyńska, A.; Czekała, W.; Janczak, D. Energy and economic potential of maize straw used for biofuels production. In MATEC Web of Conferences; EDP Sciences: Ullis, France, 2016; Volume 60, p. 4008. [CrossRef]

106. Sieborg, M.U.; Jønson, B.D.; Larsen, S.U.; Vazifehkhoran, A.H.; Triolo, J.M. Co-Ensiling of Wheat Straw as an Alternative Pre-Treatment to Chemical, Hydrothermal and Mechanical Methods for Methane Production. Energies 2020, 13, 4047. [CrossRef]

107. Ai, P.; Chen, M.; Ran, Y.; Jin, K.; Peng, J.; Abomohra, A.E.F. Digestate recirculation through co-digestion with rice straw: Towards high biogas production and efficient waste recycling. J. Clean. Prod. 2020, 263, 121441. [CrossRef]

108. Siddique, M.N.I.; Wahid, Z.A. Achievements and perspectives of anaerobic co-digestion: A review. J. Clean. Prod. 2018, 194, 359-371. [CrossRef]

109. Misson, G.; Mainardis, M.; Incerti, G.; Goi, D.; Peressotti, A. Preliminary evaluation of potential methane production from anaerobic digestion of beach-cast seagrass wrack: The case study of high-adriatic coast. J. Clean. Prod. 2020, 254, 120131. [CrossRef]

110. Mainardis, M.; Flaibani, S.; Mazzolini, F.; Peressotti, A.; Goi, D. Techno-economic analysis of anaerobic digestion implementation in small Italian breweries and evaluation of biochar and granular activated carbon addition effect on methane yield. J. Environ. Chem. Eng. 2019, 7, 103184. [CrossRef]

Publisher's Note: MDPI stays neutral with regard to jurisdictional claims in published maps and institutional affiliations. 